\title{
Authors' reply: Vitamins in the treatment of chronic Chagas disease: adjuvant antiparasitary or antioxidant therapy?
}

\author{
Mônica Coelho Andrade ${ }^{[1]}$, Maria de Fátima Oliveira ${ }^{[2]}$, Aparecida Tiemi Nagao-Dias ${ }^{[2]}$, \\ Ivo Castelo Branco Coêlho ${ }^{[1]}$, Darlan da Silva Cândido ${ }^{[2]}$, Erlane Chaves Freitas ${ }^{[1]}$, \\ Helena Lutéscia Luna Coelho ${ }^{[3]}$ and Fernando Schemelzer Moraes Bezerra ${ }^{[1],[2],[4]}$
}

[1]. Departamento de Patologia e Medicina Legal, Faculdade de Medicina, Universidade Federal do Ceará, Fortaleza, CE. [2]. Departamento de Análises Clínicas e Toxicológicas, Faculdade de Farmácia, Odontologia e Enfermagem, Universidade Federal do Ceará, Fortaleza, CE. [3]. Departamento de Farmácia, Faculdade de Farmácia, Odontologia e Enfermagem, Universidade Federal do Ceará, Fortaleza, CE. [4]. Departamento de Saúde Comunitária, Faculdade de Medicina, Universidade Federal do Ceará, Fortaleza, CE.

\section{Dear Editor,}

We would like to acknowledge the comments regarding our article Clinical and serological evolution in chronic Chagas disease patients in a 4-year pharmacotherapy follow-up: a preliminary study ${ }^{1}$, which are contained in the letter The role of benznidazole with cyanocobalamin and ascorbic acid in treating the chronic phase of Chagas disease ${ }^{2}$.

Although pharmacotherapy with benznidazole is associated with adverse reactions and limited effectiveness in the chronic phase of Chagas disease $\mathrm{e}^{1,3}$, it has been used in the indeterminate phase of Chagas disease to reduce parasitemia, prevent visceral lesions and transmission. As well, observational studies have shown that benznidazole may even benefit patients in the cardiac chronic stage of the disease ${ }^{4}$. Moreover, despite the large number of adverse reactions caused by benznidazole administration, it is considered safe when administered by a qualified professional, as monitoring of the treatment can prevent complications ${ }^{3}$.

After reviewing the articles referenced in the letter, we have noticed that although benznidazole, when combined with both vitamins, has improved antiparasitic effects in the experimental acute phase ${ }^{5}$, this study was not designed to assess the outcomes of the chronic phase of the disease. Marim et al. ${ }^{5}$ have recently reported that vitamin $\mathrm{C}$ administration reduced parasitemia, although no effect was observed regarding the number of amastigote nets in the other tissues ${ }^{6}$. This phenomenon might limit the efficacy of the combined treatment in the chronic phase, as other researchers have reported no statistically significant histopathological differences in chronically infected mice that were treated with vitamin $\mathrm{C}$ for 180 days?

Address to: Prof. Fernando Schemelzer Moraes Bezerra. Dept ${ }^{\circ}$ de Análises Clínicas e Toxicológicas/FFOE/UFC. Rua Capitão Francisco Pedro 1210, 60430-370 Fortaleza, CE, Brasil.

Phone: 5585 3366-8242

e-mail: bezerra@ufc.br

Received 20 May 2014

Accepted 21 May 2014
Although our group has never treated chagasic patients with benznidazole combined with cyanocobalamin and ascorbic acid, Ribeiro et al. ${ }^{8}$ have conducted a study where they administered vitamins $\mathrm{C}$ and $\mathrm{E}$ for 6 months following the termination of benznidazole treatment. The authors concluded that supplementation with both vitamins reduced the oxidative stress produced by the disease itself, as well as that produced by the administration of benznidazole.

More conclusive results would be needed to demonstrate that there is a real improvement in the trypanocidal effect or clinical outcomes associated with the concomitant use of the vitamins and benznidazole in the chronic phase. Besides, vitamin $\mathrm{C}$ may exert prooxidant or antioxidant effects in a dosedependent manner ${ }^{9,10}$, and its cytotoxicity may be increased by concomitant use of vitamin $\mathrm{B} 12^{11}$. In this way, vitamin $\mathrm{C}$ might either reduce or enhance the oxidative burst when simultaneously administered with benznidazole, and therefore concerns exist regarding this treatment's efficacy and safety. On the other hand, the evidence provided by studies conducted in chronic chagasic patients may justify the use of vitamin $\mathrm{C}$ following termination of benznidazole treatment, in order to decrease the oxidative stress ${ }^{8}$.

\section{CONFLICT OF INTEREST}

The authors declare that there is no conflict of interest.

\section{REFERENCES}

1. Andrade MC, Oliveira MF, Nagao-Dias AT, Coelho IC, Candido DS, Freitas EC, et al. Clinical and serological evolution in chronic Chagas disease patients in a 4-year pharmacotherapy follow-up: a preliminary study. Rev Soc Bras Med Trop 2013; 46:776-778.

2. Ghobadifar MA, Kalani N, Gitiforouz M. The role of benznidazole with cyanocobalamin and ascorbic acid in treating the chronic phase of Chagas disease. Rev Soc Bras Med Trop 2014; 47:669.

3. Hasslocher-Moreno AM, do Brasil PE, de Sousa AS, Xavier SS, Chambela MC, Sperandio da Silva GM. Safety of benznidazole use in the treatment of chronic Chagas' disease. J Antimicrob Chemother 2012; 67:1261-1266. 
4. Sociedade Brasileira De Cardiologia. I Latin American Guidelines for the diagnosis and treatment of chagas' heart disease: executive summary. Arq Bras Cardiol 2011; 97 (suppl 1): 48p.

5. Ciccarelli AB, Frank FM, Puente V, Malchiodi EL, Batlle A, Lombardo ME. Antiparasitic Effect of Vitamin B12 on Trypanosoma cruzi. Antimicrob Agents Chemother 2012; 56:5315-5320.

6. Marim RG, Gusmão AS, Castanho RE, Deminice R, Therezo AL, Jordão Junior AA, et al. Effects of vitamin C supplementation on acute phase Chagas disease in experimentally Infected mice with Trypanosoma cruzi QM1 strain. Rev Inst Med Trop São Paulo 2012; 54:319-323.

7. Gusmão AS, Castanho REP, Andrade RFA, Farsetti CM, Mathias AB, Therezo ALS, et al.. Vitamin C effects in mice experimentally infected with Trypanosoma cruzi QM2 strain. Rev Soc Bras Med Trop 2012; 45:51-54.
8. Ribeiro CM, Budni P, Pedrosa RC, Farias MS, Parisotto EB, Dalmarco EM, et al. Antioxidant therapy attenuates oxidative insult caused by benzonidazole in chronic Chagas' heart disease. Int J Cardiol 2010; 145:27-33.

9. Padayatty SJ, Katz A, Wang Y, Eck P, Kwon O, Lee JH, et al. Vitamin C as an antioxidant: evolution of its role in disease prevention. J Am Coll Nutr 2003; 22:18-35.

10. Ferreira ALA, Matsubara LS. Radicais livres: conceitos, doenças relacionadas, sistema de defesa e estresse oxidativo. Rev Ass Med Bras 1997; 43:61-68.

11. Solovieva ME, Soloviev VV, Akatov VS. Vitamin B12b increases the cytotoxicity of short-time exposure to ascorbic acid, inducing oxidative burst and iron-dependent DNA damage. Eur J Pharmacol 2007; 566:206-214. 